\title{
Erken Cumhuriyet Döneminden Günümüze Çocuk Edebiyatındaki Çevre Odaklı Kültürel Sözcüklerin Çevirisine Niceliksel Bir Yaklaşım*
}

\author{
Neslihan Kansu-Yetkiner ${ }^{1}$, Derya Duman ${ }^{2}$, Yasemin Yavuz ${ }^{3}$, Merve \\ Avşaroğlu ${ }^{4}$ \\ ORCID ID: ${ }^{1} 0000-0002-8703-2069,{ }^{2} 0000-0002-1604-4951,{ }^{3} 0000-0003-1661-9468,{ }^{4} 0000-0002-$ \\ 6597-9091 \\ 1,2 İzmir Ekonomi Üniversitesi, Fen-Edebiyat Fakültesi, Mütercim-Tercümanlık Bölümü, \\ Balçova/İzmir \\ ${ }^{3}$ Ankara Üniversitesi, Tip Fakültesi, Biyoistatistik A.B.D., Sihhiye/Ankara \\ ${ }^{4} Y$ Yldız Teknik Üniversitesi, Sosyal Bilimler Enstitüsü, Diller ve Kültürlerarası Çeviribilim A.B.D. \\ Esenler/Istanbul \\ ${ }^{1}$ neslihan.yetkiner@ieu.edu.tr, ${ }^{2}$ derya.duman@ieu.edu.tr, ${ }^{3}$ genc@medicine.ankara.edu.tr, \\ ${ }^{4}$ merveavsaroglu@gmail.com
}

(Gönderilme tarihi 13 Mart 2018; kabul edilme tarihi 22 Теттиz 2018)

ÖZ: Betimleyici Çeviribilim temelli bu çalışmanın amacı, kültüre özgü bir öge olarak değerlendirilen çevre/doğa bilgisi içeren sözcüklerin kültürlerarası aktarımı sırasında geliştirilen çeviri yöntemlerinin dağılımlarını niceliksel verilerle tarihsel olarak belirlemek ve kültür ögelerinin çevrilmesi açısından çocuk edebiyatı kapsamında öncül bir yöntem haritası oluşturmaktır. Çalışmanın veri tabanını doğada serüven, insan-doğa mücadelesi, insanhayvan dostluğu temalı, özgün dili İngilizce olan 10 çocuk klasiği ve bu eserlerin 1929-2013 y1llarında basılan 48 yeniden çevirisi oluşturmaktadır. Çalıșmamızın bulguları, erken Cumhuriyet döneminde en fazla sözcüğü sözcügüne çeviri yönteminin kullanıldığını; daha sonraki dönemlerde çeviri sürecine egemen olan yöntemlerin sırasıyla yerlileștirme, sözcüğü sözcüğüne çeviri ve yabancılaştırma olduğunu ortaya koymuştur. Sonuçlar, tarihsel süreçte ülkenin sosyo-kültürel ve politik koşullarıyla bağdaştırılarak incelenmiştir.

Anahtar sözcükler: çeviri çocuk edebiyatı, çeviri yöntemleri, çevre odaklı kültürel ögeler, yerlileştirme, yabancılaştırma

A Quantitative Approach to Methods Used in Translated Children's Literature during the Translation of Environment-based Cultural Words from the Early Republican Period to the Present

ABSTRACT: Based upon Descriptive Translation Studies, the primary purpose of this study is to define the diachronic distribution of translation methods

\footnotetext{
* Bu çalışma, TÜBİTAK 1001- Bilimsel ve Teknolojik Araştırma Projeleri kapsamında 115K145 no.lu proje çerçevesinde desteklenmiştir.
} 
formulated in the intercultural transfer of environment/nature information as a culture-bound element through quantitative data and to constitute a pioneering map of methods in terms of translation of cultural elements within the scope of children's literature. The database of the study is composed of 10 English children's literature classics with the themes of adventure in nature, humannature struggle, human-animal friendship and their 48 retranslations published between 1929 and 2013. The findings of our study have revealed that literal translation was the most used translation method in the early Republican period and that the methods prevailing the translation process in the other periods were domestication, literal translation and foreignization, respectively.

Keywords: translated children's literature, translation strategies, cultural elements, domestication, foreignization

\section{Giriş}

Uygar toplumların önüne büyük bir sorun olarak çıkmış olan çevre meselesine ilişkin farkındalıkların çok küçük yaşlardan itibaren bireylere kazandırılması gerekliliği günümüzde tartışılmaz bir gerçektir. Çocuklar kültürel normları ve ideolojileri birçok farklı şekilde edinseler de edebiyat bu sosyalleşmenin ve kültür ediniminin önemli bir bileşenidir. Çünkü çocuklar anlatılarda ve imgelerde gördükleri davranışları modelleme eğilimindedirler. $\mathrm{Bu}$ bakış açısıyla, çocukların çevreye ilişkin olumlu tavır almaları ya da çevre hakkında bilgilerini artırmaları için edebiyat en etkin araçlardan biridir. Çocuk edebiyatı diğer yazın metinlerinin aksine, öğretici bir kapsama sahiptir. Hunt'a (1994) göre, çocuk edebiyatının bir biçimde etkili ve eğitici olmaması olanaksızdır. Bu nedenle, çocuk edebiyatı yazarları sadece bir öyküleme yapmanın ötesinde kültürel değerlerin aktarımından da sorumludur. Benzer şekilde, çocuklara toplumsal ahlakın kazandırılmasında edebiyatın önemine değinen Baratz ve Hazeria (2012) edebiyatın çevre ve sürdürülebilirlik konularının öğretilmesinde çok önemli bir araç görevi gördüğünü ifade etmektedir. Çocuk kitaplarının sunabileceği psikolojik, duygusal, dilbilimsel ve edebi bileşenler sayesinde edebiyat çocukların çevre okuryazarlığı geliştirmelerinde altyapı niteliği taşıyabilir. Edebiyat, sosyal bir değer olarak çocuklara doğa-hayvan sevgisini ve doğayı koruma güdüsünü önde gelen değerler olarak sunarken aynı zamanda bilginin yayılmasina da hizmet eder.

1980'lerden itibaren gerçekleşen Çeviribilim'deki paradigma değişimi, alanı kuralcı araştırma yöntemlerinden uzaklaştırarak betimleyici ve çözümleyici bakış açısıyla kültürel süreçlere yöneltmiştir. Sosyo-kültürel tutum ve ideolojik söylemler ile çok farklı güç odaklarının çalışma kapsamına sokulmasıyla Çeviribilim günümüzde halen dokunulmamış bakir konular barındıran disiplinlerarası bir kimliğe bürünmüştür. Bu yaklaşımlardan birisi de çok az sayıdaki çalışmanın yer bulduğu ekoeleştiri (ecocritisim) ve 
Çeviribilim'in kesişme noktasıdır (bkz. Hostova, 2016; Cronin, 2015; Valero Garcés, 2011). Cronin (2017) daha ziyade edebiyat ve Çeviribilim ilişkisini vurgulayan ekoeleştiri-çeviri ekseninden çıkarak ekoçeviriye, yani insan eliyle çevre değişimini sorgulayan çeviriye ilişkin tüm düşünce ve uygulama biçimleri olarak çok daha geniş bir perspektifte yorumladığı ekoloji ve çeviri kesişmesine yönelmiştir. Belli bir kültür içinde bulunan çevreye ilişkin temel kavramları edinme, çevre kaygısı taşıma, çevresel sorunları çözmek için gereken becerileri kazanma, çevrenin geliştirilmesine ve iyileştirilmesine yönelik farkındalık kazanma gibi edinçleri barındıran çevre okuryazarlığının (Roth,1992) çeviri yoluyla kültürlerarası aktarımına odaklanan geniş ölçekli bir projenin parçası olan bu çalışma, Cronin'in ekoçeviri kavramı içinde yer alabilecek düzlemde, belli bir kültür içinde bulunan çevreye ilişkin temel kavramların edinilmesi bağlamında çevre odaklı sözcüklerin kaynak dilden erek dile aktarılmasına yoğunlaşmıştır. Çevreye ilişkin bilgi, tutum ve davranışları bir bütün olarak ele alan ortak zemin edebiyat olduğu ve çevre odaklı bilgi yükünün aktarımı edebiyat içinde çocuklar açısından işlevsellik kazandı̆̆ için çalışmamız çocuk edebiyatı üzerine odaklanmıştır.

Çevre ve kültür arasındaki bağlantıya vurgu yaparak doğa öğretisini aşılayan, tüm dünyadaki farklı sesleri içinde barındıran ve sınırları sürekli genişleyen çevre odaklı çocuk edebiyatı hiç şüphesiz ki "çeviri edebiyatı" da kapsar. Bu kapsam, çeviri yoluyla kültürlerarası aktarımda sadece yerel ve küresel olarak çevre bilincinin oluşturulması bakımından değil, "öteki" ye ilişkin bir bilgi donanımının edinilmesi bakımından da önemlidir. Çeviri çocuk edebiyatı çocukların yanı başında olmayan ya da gerçekleşmeyen doğal varlık ve olguları, örneğin tropik yağmur ormanları, Kuzey Alaska tundraları, morina balığı, deniz çileği veya ekmek ağacı gibi çocuğun deneyimleriyle doğrudan örtüşmeyen gerçeklikleri sunmak suretiyle bilgi yükünün arttırılmasına yardımcı olur. Çevirmeni ve çeviri eylemini, çevre bilinci edinmenin ve çevreye yönelik tutum ve eylem oluşturmanın tam ortasına koyan bu çalışma, aslında salt çevre sözcüklerinin aktarımından öte, farklı çevre kültürlerini tanıtma ve aktarmada bilinç düzeyini ortaya koymayı, şimdiye kadar oluşmuş yerleşik söylem düzenine betimleyici ve çözümleyici bir bakış açısı getirmeyi amaçlamaktadır.

Coğrafi şekiller, iklim, hayvan çeşitliliği, bitki örtüsü vb. çevre odaklı ögelerin birçok çeviribilimci tarafindan kültürün alt bileşenleri olarak kabul edilmesine karşın, bu tür ekolojik ögelerin kültürlerarası aktarımı tek başına henüz hiç ele alınmamıştır; dolayısıyla ihmal edilmiş bir kültür alt kategorisini oluşturmaktadır. Diğer deyişle, çevreye ilişkin başka bir kültürdeki kavramları, varlıkları ve olguları öğrenmek ve çevre bilinci edinmek gibi edinçlerin çeviri yoluyla kültürlerarası aktarımı, çevre söyleminin taşınması ve doğru mesajların iletilmesi açısından bakir bir 
çalışma alanını oluşturmaktadır. Öte yandan, çevirmen için çocuk edebiyatı kapsamında kaynak kültüre ait yabancı ögeleri yerlileştirerek erek dile aktarmak veya bunları yabancı ögeler olarak koruyup erek dil okurunda bir farkındalık yaratmak temel çeviri davranışları olarak karşımıza çıkmaktadır. Ancak çeviri yöntemleri ile ilgili düzenli örüntüler makro düzeyde kültür politikaları ile yakından ilişkili olup çevirmenin kişisel kararlarından ziyade o dönemin sosyo-politik ve kültürel dinamiklerini yansıtmaktadır.

$\mathrm{Bu}$ çerçeveden hareketle, bu çalışma Betimleyici Çeviribilim çerçevesinde doğada serüven, insan-doğa mücadelesi, insan-hayvan dostluğu temalı, özgün dili İngilizce olan 10 çocuk klasiğinin 1929-2013 yıllarında basılan 48 yeniden çevirisinde çevre bilgisinin kültürlerarası aktarımlarındaki çeviri yöntemlerinin dağılımlarını incelemeyi amaçlamaktadır. $\mathrm{Bu}$ amaç doğrultusunda (i) Çevresel/ekolojik bilgi yükünün aktarımında kullanılan çeviri yöntemleri belirlenecek, ii) Artsüremli bir bakış açısıyla, bir kültürel alt alan olarak çevre odaklı ögelerin çevirisindeki yöntem tercihleri 1929-1960, 1961-1980, 1981-2013 dönemleri temelinde incelenecek ve çocuk edebiyatı bağlamında kültürel aktarımlara yönelik bir çeviri yöntemleri haritası çıkarılacaktır. Söz konusu zaman dilimlerinin belirlenmesine ilişkin çerçeve $4.3^{\prime}$ te ayrıntılı olarak verilmiştir.

Çevresel/ekolojik bilgi yükünün aktarımını çeviri edebi eserler kapsamında kültürel bir boyut olarak değerlendiren bu betimleyici çalışmanın bundan sonraki bölümlerinde Çeviribilim'de kültüre özgü ögeler çerçevesinde çevre konusu ele alınacaktır. Ardından, Türkiye'de çeviri çocuk edebiyatının gelişimi ve çocuk edebiyatı bağlamında çeviri yöntemleri irdelenecektir. Veri tabanı ve yöntemin açıklanmasından sonra çözümlemeler kısmında çeviri yöntemlerinin genel dağılımı, anlam kategorilerine göre dağılımı ve dönemsel dağılımı üzerinde durulacaktır. Çalışmamız, tartışma ve sonuç bölümüyle sona erecektir.

\section{1 Çeviribilim'de Kültüre Özgü Ögeler ve Bir Alt Kategori Olarak Çevre}

20. yüzyılın ikinci yarısında dilbilim odaklı bakış açısından uzaklaşan Çeviribilim; insan, toplum, kültür ve ideoloji bileşenlerini çalışma alanına dâhil etmiştir. Doksanların başında, Bassnett ve Lefevere'in (1990) öncülüğündeki "kültür dönemeci" yaklaşımı, çeviri ediminin sadece dilbilgisel aktarım bakımından değil, ideoloji, kültür, güç odaklarının denetimi (patronaj) gibi kavramları barındıran kültür odaklı kuramlar bakımından da ele alınması gerektiğinin altını çizmektedir. Lefevere'e (1992) göre, çeviri yalnızca bir başka dünyaya açılan bir pencere değil, daha ziyade yabancı etkisinin yerli kültürün içine işlediği, hatta zorlayıp tahrip ettiği, çoğunlukla kendiliğinden açılan bir kanaldır. Goodenough'ın (1964, s.36) daha kapsayıcı bir bakış açısıyla tanımladığı şekliyle kültür, "maddesel bir olgu olmayıp, nesneleri, 
kişileri, davranış ve duyguları içermez. Kültür daha ziyade sayılan bu kavramların bir teşekkülüdür. İnsanların zihnindeki, algılama ve koşullarla başa çıkma modellerindeki şeylerin biçimlenişidir” (Çeviri yazarlara aittir.).

Özellikle yazınsal metinlerde kültür odaklı ögelerin belirlenmesi ve çevirisi önemli ve tartışmalı bir çalışma alanını oluşturmaktadır. Aixela'ya (1996, s.58) göre, "kültüre özgü sözcükler, kaynak dilde işlevi ve yan anlamları metinsel olarak önem taşıyan ögelerin erek metne aktarımı sırasında, bu ögelerin erek kültür okuru için bir karşılığı olmadığında veya erek kültürde farklı bir metinlerarasılık özelliğinin olması durumunda sorun çıktığı zaman anlaşılır" (Çeviri yazarlara aittir.). Daha çok bir çeviri sorunu veya çevrilemezlikle bağdaştırılan bu kültüre özgü ögelerden dolayı çevirinin yapılması çoğu kez imkânsız ya da zor görünmektedir; çünkü söz konusu ögelerin altında yatan anlamlar daima özel bir kültürel bağlamla sıkı sıkıya bağlantılandırılmıştır (Baker, 1992). Söz konusu ögeler için çeviri yazınında realia, kültüre özgü ögeler ve kültüre bağlı ögeler gibi birçok ifade bulunmaktadır. Sadece materyal kültürün nesnelerini değil aynı zamanda özel bir kültürle ilgili olan kavramları da belirtmek için realia kavramını ortaya atan Vlahov ve Florin (1969, Florin 1993'ten) bu kavramın içerisindeki unsurları coğrafi ögeler (belirli bir yere özgü coğrafi oluşumlar, insan yapımı coğrafi nesneler, bitki örtüsü ve hayvan toplulukları), etnografik ögeler (yiyecek ve içecek, kıyafet, mekânlar, mobilya, taşıtlar, meslekler ve araçgereçler), sanat ve kültür ögeleri (müzik ve dans, müzik enstrümanları, bayramlar/festivaller, oyunlar ve ritüeller), etnik ögeler (insanların isimleri ve lakaplar/takma adlar), sosyo-politik ögeler (idari-bölgesel birimler, makamlar ve temsilcilikler, rütbeler ve askerî ögeler) şekilde sıralamaktadır.

Benzer şekilde, kültürü yaşam tarzı olarak tanımlayan Newmark (1988), kültürel sözcükleri belirli bir dili ifade aracı olarak kullanan bir topluma özgü olan kültürün dışavurumları olarak ifade etmektedir. Bundan dolayı Newmark, her bir dil grubunun kendine özgü kültürel özellikleri olduğunu kabul etmekte ve kültürel kelimeleri ekoloji (bitki örtüsü, hayvan toplulukları, tepeler, rüzgârlar, ovalar), materyal kültür, sosyal kültür, organizasyonlar, gelenek ve görenekler, aktiviteler, kavramlar ve son olarak jestler ve alışkanlıklar başlıkları altında sınıflandırmaktadır.

Görüldüğü üzere, çeşitli araştırmacılar tarafindan çevre ve çevreyle ilişkili konu başlıkları kültüre özgü kavramlar bağlamında hedef dilde doğrudan bir karşıllğı olmayan bir kültür alt kategorisi olarak değerlendirilmektedir. O halde, çevre odaklı bilgi yükünün aktarımı da diğer kültür ögelerinin aktarımında olduğu gibi ele alınması gereken bir olgudur. Üstelik diğer kültür ögelerinden farklı olarak çevre odaklı kültürel ögelerin aktarımı hem ekosisteme yönelik bilgi yükünü hem de çevre bilincine bağlı bir tutum söylemini içinde barındırır. 


\subsection{Türkiye'de Çeviri Çocuk Edebiyatı ve Çocuk Edebiyatı Bă̆lamında Çeviri Yöntemleri}

19. yüzyıla kadar, Türk çocuk edebiyatı Karagöz oyunları, Nasrettin Hoca fikraları ve Keloğlan masalları gibi ürünlerle sözlü gelenek şeklinde var olmuştur. Tanzimat Döneminde Şinasi'nin La Fontaine'den yaptığı fabl çevirileri, Doktor Rüștü'nün Nuhbetü'l-Etfâl adlı kitabının sonuna eklediği çocuk hikâyeleri ve fabl çevirileri ve son olarak Yusuf Kamil Paşa'nın Fenelon'dan çevirdiği Telemak adlı roman çocuk edebiyatına büyük ivme kazandırmıştır (Çıkla, 2005). Ayrıca, bu dönemde Daniel Defoe'nun Robinson Crusoe ve Jonathan Swift'in Gulliver adlı romanları, çevirisi yapılan ilk eserler olmuştur. Türk çocuk edebiyatındaki boşluk, yabancı eserlerin çevirileri yapılarak doldurulmaya başlandıktan sonra, telif eserlerin sayısında da artış söz konusudur. Ahmet Mithat Efendi'nin Hâce-i Evvel (1870) ve Kissadan Hisse (1871), Recaizade Mahmut Ekrem'in Tefekkür (1886), Muallim Naci'nin Ömer'in Çocukluğu (1890) adlı kitapları ile Tevfik Fikret'in Şermin (1914), Ziya Gökalp'in Kızıl Elma (1915), Ali Ekrem Bolayır'ın Şiir Demeti (1923) adlı eserleri, bu gruba dâhildir (Çıkla, 2005). Tanzimat Dönemi ile birlikte ilk yayınlanan çocuk dergisi Mümeyyiz (1869) olmuş, çocuklara yönelik haftalık ya da aylık olarak gazete, mecmua, ceride, risale adları altında yayınlar yapılmaya başlanmıştır (Güran Yiğitbaşı, 2014).

Erken Cumhuriyet döneminde çocuk edebiyatı açısından meydana gelen en önemli gelişme 1940'lı yıllarda klasiklerin devlet imkânları aracılığıyla yoğun olarak çevrilmesidir. Hasan Âli Yücel'in Milli Eğitim Bakanlığı yaptığı bu yıllarda Batı klasikleri ile birlikte pek çok çocuk edebiyatı kitapları da Türkçeye çevrilmiştir. Bu dönemde kurulan Tercüme Bürosu, "Batı kültürünün başyapıtlarını Türkçeye kazandırarak kültürel açılım yaratmaya çalışmıştır” (Neydim, 2003, s.91). Bu gelişmeye, Çocuk Esirgeme Kurumu'nun yine aynı yıllarda çoğu çeviri olmak üzere pek çok çocuk kitabı bastırması eşlik etmiştir.

1945 sonrası çok partili döneme geçişle birlikte sosyal konuları da kapsayacak biçimde değişiklikler görülmeye başlanmıştır. Bu bağlamda Türk çocuk edebiyatına eserler kazandıran yazarlar arasında Talip Apaydın, Mehmet Seyda, Gülten Dayığlu, Aziz Nesin ve Rıfat Ilgaz gösterilebilir. Bu süreçte, yayınevleri de giderek artan şekilde çocukları edebiyat ürünleriyle buluşturma isteği göstermişlerdir. Örneğin, Doğan Kardeş yayınları, başta dünya çocuk klasikleri olmak üzere pek çok eserin çevirisini yüksek kaliteli kitaplara dönüştürmüştür (Tuncer, 1995).

1960-1980 yıllarında 68 öğrenci hareketinin de etkisiyle eleştirel politik duruş edebiyat eleştirisine bir zemin oluşturmuş ve edebiyatta siyasi ve sosyal içerikli yaklaşımların geliştirilmesinin önünü açmıştır. "İyi kitap" kavramın sorunsallaştırıldığı bu dönemde, çocuk edebiyatı daha büyük bir ciddiyetle ele alınmaya başlanmış ve çocuk edebiyatı ile eşitlik, özgürlük, estetik gibi 
kavramlar birlikte anılır olmuştur (Neydim, 2000, s.68). 1970'li yıllar, hem telif hem çeviri eserler açısından, çocuk edebiyatı ürünlerinde sol düşüncenin öne çıktığı yıllar olarak görülebilir (Neydim, 2000). Bu süreçte yaşanan bir diğer önemli gelişme de 1979 yılına aittir. 1979 yılı, Uluslararası Çocuk Yılı olarak kabul edildiği için, özellikle bu yılda çocuk kitapları basımında hem nicelik hem de nitelik açısından çok büyük bir atılım gerçekleşmiştir (Tuncer, 1995). 1970'li yıllarda daha fazla telif eser üretme yoluyla Türk çocuk edebiyatını güçlendirme çabaları yine de istenilen hedefe ulaşamadığından, çeviri eserler önemini korumaya devam etmiştir (Neydim, 2000).

1960-1980 yılları arasında genel olarak masalları ve fablları en çok çevrilen yazarlar içerisinde Grimm Kardeşler, Andersen ve La Fontaine yer alırken, roman türünde en çok çevirisi yapılan yazar yine Jules Verne olmuştur (Çıkla, 2005, s.98). Önemli Türk edebiyatçılarının eserlerine yer veren Milliyet Çocuk Dergisi, Tercüman Çocuk ve Milli Eğitim Bakanlığı tarafından yayınlanan İleri Yavrutürk adlı dergiler, dönemin öne çıkan çocuk dergileri arasındadır (Güran Yiğitbaşı, 2014).

1980 sonrası dönemde, çocuk, edebiyatın bir hedef kitlesi olarak daha görünür hale gelmiş ve çocuk edebiyatı ürünleri hem siyasi hem de dinî kaygılarla yayınlanmaya devam etmiştir (Neydim, 2000). 1980 sonrası dönemde devlet denetimi olmaksızın farklı özel yayınevleri çocuk kitapları basmayı sürdürmüştür. Çeviri çocuk edebiyatı açısından en belirgin gelişme, Milli Eğitim Bakanlığı'nın 2004 ve 2005 tarihlerinde bir genelge ile tanıttığı, sırasıyla orta ve ilköğretim için hazırlanan ve bir kısmı Batı klasiklerinden oluşan 100 Temel Eser listelerinin yayınlanması olmuştur. Bu listedeki kitapların Bakanlık tarafından öğrencilere okutulmak üzere tavsiye edilmesinin ardından, klasikler yeniden çeviri yoluyla çok çeşitli yayınevlerinin basımlarıyla çocuklara sunulmuştur. Batı çocuk edebiyatı klasiklerinde İslami ögelerin öne çıkarılarak ve yerlileştirme yapılarak çevrilmesi çocuk edebiyatı çevirileri konusunda belki de cumhuriyet tarihinde ilk kez büyük bir tartışma yaratmıştır (Neydim, 2006; Daldeniz, 2010; Birkan Baydan, 2010; Kansu-Yetkiner, 2014).

Genel özellikleri açısından bakıldığında, çocuk edebiyatı, birçok bakımdan yetişkin edebiyatından farklılık göstermektedir (Shavit, 1986; Puurtinen, 1998; Frank, 2007). Öncelikle bir çocuk kitabının eğitici ve eğlendirici olması, kabul gören normlara uygunluk göstermesi ve hem aileye hem de çocuğa cazip gelmesi beklenmektedir. İkinci olarak, başlık, olay örgüsü, metinde sunulan norm ve değerler, resimler, kültürler ve diller arası aktarım açısından katı kurallar söz konusudur. Öte yandan, farklı çalışmalar (Klingberg, 1986; Puurtinen, 1998) çeviri çocuk edebiyatında yetişkin edebiyatına kıyasla çevirmene daha fazla özgürlük tanındığını yerlileştirme ve yabancılaştırma ekseninde ifade etmektedir. Erek kültürün ve dilin normlarına 
uyum sağlama yerlileştirme yöntemini ve bunun alt yöntemlerini beraberinde getirirken, bunlara direnç gösterme ve kaynak kültür normlarında diretme yabancılaştırma yöntemine yönelimi işaret etmektedir. Yerlileştirme yöntemine eğilim, erek metni kaynak kültürün yabanc1, "öteki” ögelerinin istilasından korumakta, ancak diğer taraftan erek okur için aşina, bilindik ögelerin kullanılmasıyla özgün metindeki önemli özelliklerin değiştirilmesine veya ayıklanmasına yol açmaktadır. Bu durumda çocuk okur yeni bilgiyi öğrenemeyecek, ötekiyi tanıyamayacaktır.

Çocuk edebiyatındaki özellikli okur yani okurun bir çocuk olması, ayrıca bu edebiyat türünde yetişkin edebiyatından farklı olarak akıcılık ve okunabilirlik gibi ögelerin aranması, çevirmenin hem özgürlük alanını hem de sorumluluğunu arttırmaktadır. Benzer şekilde, Frank'e (2007) göre, çocuk edebiyatı çevirilerinde kaynak metin, erek okurun anlama ve deneyim düzeyine göre uyarlama eğilimi ve kaynak metnin kültürel ortamını erek dil okuruna doğru yaklaştırma çabası söz konusudur. Çocuk edebiyatındaki önemli ögelerden sayılan akıcılık ve okunabilirlik hem metin dilinin zorluk/basitlik düzeyi ile hem de anlaşılabilirlik ile yakından ilişkilidir. Çevirmeni erek metinde okunabilirliği ve akıcılığı oluşturmaya koşullayan bu sınırlayıcı çerçevede çevirmen kararları erek okurun bilgi düzeyi, dil yetkinliği, kültürlerarası yakınlık gibi bir dizi erek dil odaklı yöntemler 1şığında şekillenmektedir.

Sonuç olarak, çocuk edebiyatı çevirileri sürecinde var olan dilbilimsel, biçemsel ve değer yargıları temelli sınırlamalar, çevirmeni başka kültürdeki çocuk okur için metni ulaşılabilir kılmaya zorlamaktadır. Bu noktada çevirmen, kültürlerarası uzlaşı veya direnç yaratılması, kültürel benzerliklerin veya farklılıkların öncelenmesi temelinde yerlileştirme veya yabancılaştırmayı bir yöntem olarak belirlerken metin, yazar, okur, kaynak ve erek kültürün hepsini kapsayan bir sorumluluğun altına girmektedir.

\section{Veri Tabanı}

Betimleyici Çeviribilim çerçevesindeki bu çalışmanın veri tabanını, özgün dili İngilizce olan 10 çocuk klasiği ve bu klasiklerin 1929-2013 yıllarında yayınlanan 48 Türkçeye yeniden çevirisi oluşturmaktadır. $\mathrm{Bu}$ klasiklerin seçiminde, çalışmada çevre odaklı bilgi yükünün kültürlerarası aktarımına odaklanıldığı için, veri tabanına dâhil edilen kitapların vahşi doğada macera, hayvan-doğa sevgisi ve insan-doğa mücadelesi gibi izleklere sahip olmasına, çevirilerin intihal olmamasına, tarihi ve çevirmeni belli olarak muteber yayınevlerinden çıkmasına özen gösterilmiştir. Veri tabanı içinde yer alan bazı kitaplar özgün olarak yetişkin edebiyatı için yazılmış olsa da günümüzde çocuk edebiyatı klasikleri içindedir. Oluşturulan veri tabanı aşağıdaki gibidir. Diğer ayrıntılar Kaynakça bölümünde verilmiştir. 
Tablo 1. Çeviri Yöntemleri Çözümlemesinde Yer Alan Kitaplar

\begin{tabular}{|c|c|c|c|c|}
\hline $\begin{array}{l}\text { Veri tabanını oluşturan çeviri } \\
\text { kitaplar }\end{array}$ & $1929-1960$ & $1961-1980$ & $1981-2013$ & Toplam \\
\hline $\begin{array}{l}\text { The Call of the Wild } \\
\text { (Vahşetin Çăgrtsi) }\end{array}$ & 1 (1935) & $\begin{array}{l}1(1968) \\
1(1978)\end{array}$ & $\begin{array}{l}1(1984) \\
1(1996) \\
1(2009)\end{array}$ & 6 \\
\hline $\begin{array}{l}\text { Black Beauty } \\
\text { (Siyah İnci) }\end{array}$ & - & $\begin{array}{l}1(1965) \\
1(1973)\end{array}$ & $\begin{array}{l}1(1997) \\
1(2005)\end{array}$ & 4 \\
\hline $\begin{array}{l}\text { The Coral Island } \\
\text { (Mercan adasi) }\end{array}$ & 1 (1943) & $\begin{array}{l}1(1967) \\
1(1980)\end{array}$ & $\begin{array}{l}1(1999) \\
1(2007)\end{array}$ & 5 \\
\hline $\begin{array}{l}\text { The Secret Garden } \\
\text { (Gizli Bahçe) }\end{array}$ & 1 (1944) & $\begin{array}{l}1(1969) \\
1(1978)\end{array}$ & $\begin{array}{l}1(1991) \\
1(2011)\end{array}$ & 5 \\
\hline $\begin{array}{l}\text { The Jungle Book } \\
\text { (Orman Çocuğu) }\end{array}$ & $\begin{array}{l}1(1936) \\
1(1954)\end{array}$ & $\begin{array}{l}1(1965) \\
1(1973)\end{array}$ & $\begin{array}{l}1(1995) \\
1(2009)\end{array}$ & 6 \\
\hline $\begin{array}{l}\text { Captains Courageous } \\
\text { (Korkusuz Kaptanlar) }\end{array}$ & - & $\begin{array}{l}1(1964) \\
1(1976)\end{array}$ & $\begin{array}{l}1(1997) \\
1(2009)\end{array}$ & 4 \\
\hline $\begin{array}{l}\text { Treasure Island } \\
\text { (Define Adasi) }\end{array}$ & $\begin{array}{l}1(1939) \\
1(1956)\end{array}$ & $\begin{array}{l}1(1961) \\
1(1970)\end{array}$ & $\begin{array}{l}1(1983) \\
1(2008)\end{array}$ & 6 \\
\hline $\begin{array}{l}\text { The Lord of the Flies } \\
\text { (Sineklerin Tanrlsl) }\end{array}$ & - & $\begin{array}{l}1(1969) \\
1(1979)\end{array}$ & 1 (1994) & 3 \\
\hline $\begin{array}{l}\text { The Wind in The Willows } \\
\text { (Söğ̈ütlükte Rüzgâr) }\end{array}$ & - & 1 (1972) & $\begin{array}{l}1(1986) \\
1(2011)\end{array}$ & 3 \\
\hline $\begin{array}{l}\text { The Red Pony } \\
\text { (Al Midilli) }\end{array}$ & 1 (1953) & $\begin{array}{l}1(1964) \\
1(1976)\end{array}$ & $\begin{array}{l}1(1983) \\
1(1995) \\
1(2003)\end{array}$ & 6 \\
\hline TOPLAM & 8 & 19 & 21 & 48 \\
\hline
\end{tabular}

\section{Yöntem}

\section{1 Çözümleme Öncesi Ön Çalışmalar}

Veri tabanında yer alan 58 kitap ABBYY FineReader ${ }^{\circledR}$ programında taranarak dijital formata çevrilmiş, tüm çözümlemeler dijital kopyalar üzerinden yapılmıştır.

Çeşitli kaynaklar ve veri tabanında yer alan kitaplar taranarak çevre odaklı bilgi yükü aktarımına yönelik olarak sekiz anlam kategorisi belirlenmiş ve bunlara ilişkin içerik aşă̆ıdaki şekilde tanımlanmıştır:

- Fauna: Hayvan alt türleri ve hayvan uzuvları.

- Flora: Bitki, sebze ve meyvelerin yanı sıra, yeşillik ve bitki örtüsü barındıran tüm alanlar. Yeryüzü Şekilleri: Fizikî bir haritada 
görülebilecek yeryüzü şekilleri (dağ, tepe, deniz, nehir), haritada yer almayan doğal yeryüzü şekli oluşumları (uçurum, fiyort, yalıyar, bayır, mağara, kayalık, sahil, kıyı), insan eliyle veya hayvanlar tarafından oluşturulmuş yeryüzü şekilleri (bent, set, gölet, baraj gölü).

- Yer Adlart: Özel ve cins isim yer adları (kasaba, köy, şehir).

- Hayvan Yaşam Alanı: Hayvanların yuva olarak yaşadığı yerler (yuva, in, kovuk çiftlik, delik).

- Íklim ve Hava Koşullart: Yağış çeşitleri (kırağı, çiğ, don, dolu, kar, yağmur), hava olayları (rüzgâr, esinti, firtına) ve rüzgâr çeşitleri (meltem, poyraz, karayel) bu kategori içindedir.

- Doğal Oluşum: Doğada var olan somut maddeler (kum, taş, çakıl, su, toprak, odun vb.), gökyüzü ve gök cisimleri (ay, güneş, yıldız, gökyüzü, dünya, gezegenler), doğada oluşan olgular (1şık, anafor, kabarcık, yakamoz, yumurta, koza, ağ gibi hayvanların yaptığı oluşumlar).

- Doğal Afet: Kasırga, çı̆̆, deprem, heyelan, sel, su taşkını vb.

Kültüre özgü sözcüklerin çeviri yöntemlerine ilişkin bir şablon oluşturmak üzere alanyazın ve oluşturulan veri tabanındaki örnekler taranmış, sözcüğü sözcügüne çeviri yerlileştirme ve yabancılaştırma ekseninde yoğunlaşan çalışmaların olduğu tespit edilmiştir. Çalışmamız üç temel çeviri yöntemi ekseninde şekillenmiştir. Bunlar: kaynak dilden erek dile aktarımda hiçbir çevirmen müdahalesinin bulunmadığı sözcüğü sözcüğüne çeviri yöntemi, erek kültürün norm ve değerlerine uyum sağlama temelli olarak sözcükleri erek kültürde yerlileştirme yöntemi ve kaynak kültürün norm ve geleneklerine sadık kalarak kaynak kültüre özgü ögeleri erek metinde tutma şeklinde tanımlanan yabancılaştırma yöntemidir. Venuti'nin (1995) yabancılaştırma ve yerlileştirme stratejileri ekseninde, Newmark (1988: 103), ve Axiele'in (1996: 60-65) strateji sınıflamalarından adapte edilerek kültüre özgü terimlerin çevirisine yönelik olarak veri tabanımızdaki örnekleri değerlendirmek üzere yerlileştirme ve yabancılaştırma alt başlıkları için aşağıdaki sınıflandırma ve alt kategoriler oluşturulmuştur. 
Tablo 2. Yerlileştirme ve Yabancılaştırma Yöntemi Alt Stratejileri

\begin{tabular}{cc}
\hline Yerlileştirme & Yabancılaştırma \\
\hline Eşanlamlılık (Synonym) & Metin Dışı Açıklama (Extratextual Gloss) \\
Sinırlı Evrenselleştirme (Limited & Metin İçi Açıklama (Intratextual Gloss) \\
Universalism) & Yazımsal Uyarlama (Ortographic Adaptation \\
Tam Evrenselleştirme (Absolute & /Transcription) \\
Universalism) & Tekrar (Repetition) \\
Açımlama (Paraphrase) & Yapısal Ödünçleme (Calque) \\
Uyarlama (Adaptation) & İkili-Üçlü Strateji (Couplets, Triplets) \\
Silme (Omission) & Ödünçleme (Loan Words) \\
Belirtikleştirme (Explicitation) & \\
Anlam Çözümlemesi (Componential & \\
Analysis) &
\end{tabular}

Yerlileştirme ve yabancılaştırma yöntemlerinin sınıflamasında yer alan alt stratejilerin tanımları veri tabanından alınan örnekler eşliğinde aşağıda verilmiştir.

Yerlileştirme Alt Stratejileri:

- Eşanlamlılık: Aynı varlık ya da kavramı karşılayan farklı sözcüklere eş anlamlı sözcükler adı verilir. Çalışmamızda bir sözcüğün sözlükteki birinci anlamı veriliyorsa sözcüğü sözcüğüne çeviri, ancak beşinci ya da altıncı karşılığı veriliyorsa eş anlamlı olarak kabul edilmiştir.

- Sınırlı Evrenselleştirme: Çevirmen, sözcüğü sözcüğüne çeviri yerine yine kaynak dilde var olan, ama erek dil okurunun daha aşina olduğu bir karşılığ 1 seçmektedir. Örneğin tropik meyvelerden çevrilmesi gereken sözcük "papaya" ise bunu daha fazla bilinen "mango" sözcüğü ile karşılamaktadır.

- Tam Evrenselleştirme: Bir sözcüğü bir kapsayıcı terim kullanarak çevirme. "Meşe ağacı" yerine "ağaç", "hamsi" yerine "balık" karşılığını kullanmak gibi.

- Açımlama: Metin içindeki erek okura yabancı bir kavramı metne yedirerek (yabancı bir kavram olduğunu hissettirmeden) açıklama yapma veya açıklama yaparak çevirme. Örneğin jackfruit için "tadı ananasla mango arası kocaman kabak irisi bir meyve", lagoon için “kıyı gölü”. 
- Uyarlama: Kaynak dildeki kültür odaklı bir sözcüğün erek dildeki karşılığının verilerek çevrilmesi. Örneğin, conch veya shell sözcüklerinin "şeytan minaresi” olarak çevrilmesi.

- Silme: Kaynak metindeki kültürel ögelerin erek dilde çevrilmemesi.

- Belirtikleştirme: Kaynak metinde yer almayan sözcüklerin erek kültürde metnin daha iyi anlaşılması için eklenmesi: It/that/this gibi sözcüklerin yerine isim konması. "We killed the pigs, we ate them all." ifadesinin "Domuzları öldürdük ve domuzların hepsini yedik." şeklinde çevrilmesi gibi.

- Anlam Çözümlemesi: Bir sözcüğün sözcüğü sözcüğüne karş1lığ1 şeklinde değil de benzer anlama sahip bir sözcük olarak çevrilmesi. Örneğin: Trunk'ın ağaç gövdesi yerine kütük olarak çevrilmesi. "Yanlış çeviri” gibi gözüken durumlar aslında anlam çözümlemesi dâhilinde değerlendirilebilir. Örneğin, weed, "yosun” olarak çevrilmişken "weed"in anlam evrenine bakınca, uzak bir karşılık olsa da bir bitki türü olan "yosun” olarak çevrilmesi olasıdır.

Yabancılaştırma Alt Stratejileri:

- Metin Dışı Açıklama: Çevirmenin notu, kitap sonu ek bilgiler, dipnotlarla yapılan açıklamalar.

- Metin Içi Açıklama: Bir sözcüğü metin içinde, ama yabancı bir öge olduğunun altını çizerek açıklama. Örneğin: Amerikalılar için klasik bir pazar günü etkinliği olan mangal partisi.

- Yazımsal Uyarlama: Sözcügüun çevrilmeden erek dil normlarına uyarak aktarılması. Örneğin: Cleveland: Klivlend, Pacific: Pasifik şeklinde çevrilmiştir.

- Tekrar: Kaynak dildeki sözcüğün hiçbir değişiklik yapılmadan aynen aktarılması. Örneğin: Seattle, "Seattle" şeklinde çevrilebilir.

- Yapısal Ödünçleme: Kaynak dildeki sözcügün sözcüğü sözcügüne yapısal aktarımla çevrilmesi. Örneğin: creeping plants: sürüngen bitkiler. Türkçede böyle bir kullanım yoktur. Bu nedenle bu kullanım Türkçede garip bir ad öbeğinin oluşmasına yol açmakta ve Türkçede olmayan bir sözcük oluşturmaktadır.

- İkili Üçlü Strateji: Bir sorunu çözmek için birden fazla stratejiyi bir arada kullanmak. Örneğin, Granite rock: Granit iri taş (yazımsal uyarlama+açımlama) için hem granite sözcüğü Türkçeleştirilmiş hem de rock sözcüğünün açıklaması yapılmıştır.

- Ödünçleme: Erek dilde çeviri olarak yabancı kökenli sözcükleri kullanmak. Örneğin, Beach: plaj. 
Çevre odaklı sözcüklerin çeviri yöntemlerinin çözümlemelerinde 48 kitab1 incelemek üzere sistematik örnekleme yöntemi kullanılmıştır. Bu örnekleme yöntemi kitabın toplam sayfa sayısına göre belirlenen ve belirli aralıklarla seçilen; dolayısıyla bir kitabın başından, ortasından ve sonundan sistematik olarak sayfa seçmeye olanak tanıyan bir yöntemdir. Bu yöntemle özgün kitaplardan 10'ar sayfalık bölümler belirlenerek bu sayfalar göz önüne alınarak çözümlemeler yapılmıştır.

Çalışma yöntemi olarak öncelikle, belirlenen anlam kategorileri temelinde çevre odaklı bir içerik çözümlemesi gerçekleştirilmiştir. Buna göre, daha önceden sistematik örnekleme yöntemi dâhilinde belirlenen 10'ar sayfalık bölümlerde yer alan ve 8 anlam kategorisi içinde yer alan sözcükler, dijital formattaki kaynak metinlerde her biri ayrı bir anlam kategorisini temsil eden farklı renklere boyanmış ve sonuçlar Excel dosyasına aktarılmışıtır. Ardından, farklı renklerle kaynak metinde belirlenen (Örneğin; flora kategorisindeki sözcükler yeşile, faunadakiler kırmızıya boyanmıştır.) sözcüklerin karşılıkları erek metinde taranmış, bunların çevirisinde hangi yöntemin kullanıldığı oluşturulan yerlileştirme ve yabancılaştırma şablonları çerçevesinde saptanmıştır.

Yöntemin belirlenmesinin ardından, çözümlemelere geçmeden önce, Vahşetin Çağrısı kitabından 10 sayfalık bir bölüm seçilerek üç çözümlemeciden belirlenen yönteme göre verilen sayfalardaki çeviri odaklı sözcüklere iliş̧kin çeviri yöntemlerini incelemeleri istenerek bir pilot çalışma yapılmıştır. Bu pilot çalışma sonucunda, üç çözümlemecinin aynı 10 sayfa için İngilizce ve Türkçe metin üzerindeki çalışma sonuçları arasındaki uyum, sınıf içi korelasyon yöntemiyle hesaplanmış (ICC-Intraclass correlation coefficient) ve çözümlemeciler arası uyum anlamlı çıkmıştır (ICC=0,999, $\mathrm{p}<0,001)$. Bu uyum hesaplamasının ardından kitaplar çözümlemeciler arasında bölüştürülerek hepsi üstte belirtilen yöntem temelinde taranmıştır.

\section{4 Çevre Odaklı Sözcüklerin Çeviri Yöntemleri Çözümlemeleri ve Bulgular}

$\mathrm{Bu}$ aşamada sözcüğü sözcüğüne çeviri, yerlileştirme ve yabancılaştırma yöntemlerini kullanmak suretiyle 48 kitapta 10 'ar sayfalık bölümler içinde taranan çevre konulu anlam kategorileri dâhilindeki sözcüklerin çevrilmesine ilişkin, çeviri yöntemlerinin genel dağılımı, çeviri yöntemlerinin oluşturulan anlam kategorilerine göre dağılımı, çeviri yöntemlerinin 1929-1960, 19611980, 1981-2013 dönemlerinde olmak üzere; artsüremli seyri, istatistiksel hesaplamalarla değerlendirilmiştir. 


\section{1 Çeviri Yöntemlerinin Genel Dağılımı}

Tablo 3'ten de görüleceği üzere, incelenen 48 kitabın her birinden sistematik örnekleme yöntemiyle seçilen 10 sayfada çevre konulu ortalama 223 \pm 74 sözcüğe rastlanmıştır. Sözcüklerin hangi yöntemlerle çevrildikleri incelendiğinde sözcüğü sözcügüüe çevrilen sözcük ortalaması $91.8 \pm 60.5$, yerlileștirilen sözcük ortalaması $124,4 \pm 54,4$ ve yabancılaştırılan sözcük ortalamasının $6.8 \pm 7.6$ olduğu görülmektedir (bkz. Tablo 3). Sözcüklerin ortalama $\% 57,6 \pm 22$ ile en fazla yerlileştirme yapılarak çevrildiği, bunu ortalama \%39,1 $\pm 20,7$ ile sözcüğ̈̈ sözcügüne çevirinin ve $\% 3,3 \pm 4,2$ ile yabancılaştırma yapılarak çevrinin izlediği görülmektedir (bkz. Tablo 3, Grafik 1).

Tablo 3. 48 Kitabın 10’ar Sayfasında Çevre ile Illgili Toplam, Sözcüğ̈̈ Sözcüğ̈̈ne Çeviri Yapılmış, Yerlileştirilmişv ve Yabancılaştırılmış Sözcük Sayıları ve Yüzde Dağılımlara İlişkin Tanımlayıcı Ístatistikler

\begin{tabular}{ccccc}
\hline & \multicolumn{2}{c}{ Ortalama Sözcük Sayıları } & \multicolumn{2}{c}{ Yüzde Dağılımları (\%) } \\
\hline Yöntemler & Ortalama $\pm S S$ & $\begin{array}{c}\text { Ortanca } \\
\text { (Min-Maks) }\end{array}$ & Ortalama \pm SS & $\begin{array}{c}\text { Ortanca } \\
\text { (Min-Maks) }\end{array}$ \\
\hline $\begin{array}{c}\text { Sözcüğü } \\
\text { Sözcüğ̈ne Çeviri }\end{array}$ & $91.8 \pm 60.5$ & $84.5(4-199)$ & $39.1 \pm 20.7$ & $\begin{array}{c}40.7(2.9- \\
73.2)\end{array}$ \\
Yerlileştirme & $124.4 \pm 54.4$ & $117(36-278)$ & $57.6 \pm 22$ & $\begin{array}{c}57.2(25- \\
97.1)\end{array}$ \\
Yabancılaştırma & $6.8 \pm 7.6$ & $5(0-36)$ & $3.3 \pm 4.2$ & $2.5(0-22.1)$ \\
\hline Toplam & $223 \pm 74$ & $222(98-408)$ & - & - \\
\hline
\end{tabular}

SS: Standart Sapma

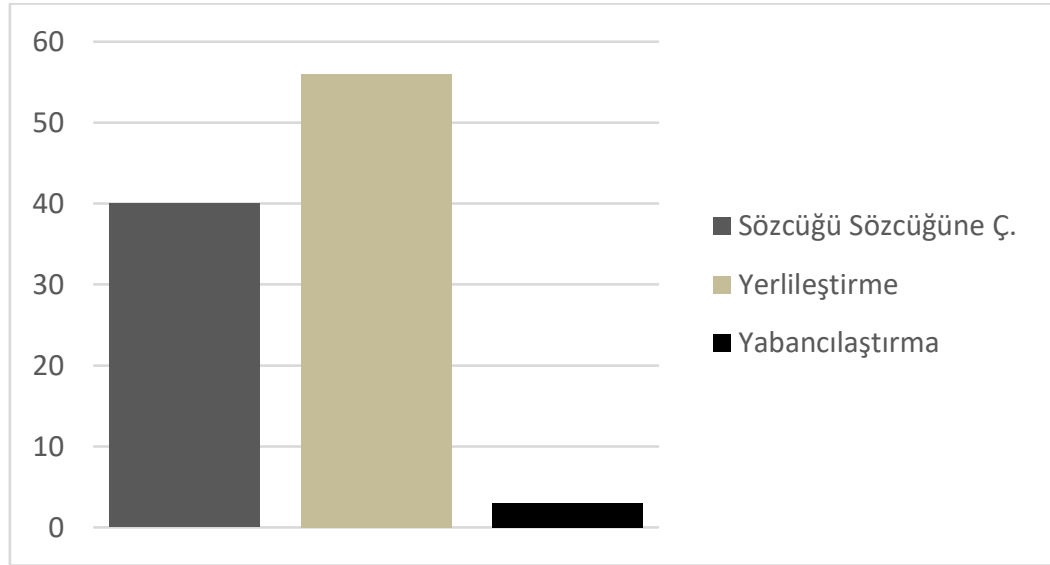

Grafik 1 Çeviri Yöntemlerinin Dă̆llım Yüzdeleri 


\subsection{Oluşturulan Anlam Kategorilerinde Çeviri Yöntemlerinin Dă̆ılımı}

48 kitabın 10'ar sayfasındaki çevre ile ilgili sözcükler anlam kategorilerine göre sınıflandırıldığında en sık Fauna kategorisindeki sözcüklere rastlanırken bunu Doğal Oluşum, Flora, Yeryüzü Şekilleri, Yer Adları, Hava/İklim Koşulları, Hayvan Yaşam Alanları ve Afet kategorileri izlemiştir (bkz. Tablo 4).

Tablo 4. 48 Kitabın 10'ar Sayfasında Çevre ile İlgili Sözcük Sayılarının Anlam Kategorilerine Göre Dă̆llımına İlişkin Tanımlayıcı İstatistikler

\begin{tabular}{ccc}
\hline & \multicolumn{2}{c}{ Sözcük Sayısı } \\
\cline { 2 - 3 } Anlam Kategorileri & Ortalama \pm SS & Ortanca (Min-Maks) \\
\hline Fauna & $88.4 \pm 73.4$ & $90.5(7-264)$ \\
Flora & $36.9 \pm 21.8$ & $40(8-99)$ \\
Yeryüzü Şekilleri & $27.1 \pm 17.4$ & $23.5(3-71)$ \\
Yer Adları & $13.4 \pm 9.9$ & $10(1-43)$ \\
Hayvan Yaşam Alanları & $7.6 \pm 8.8$ & $5.5(0-30)$ \\
Hava/İklim Koşulları & $9.5 \pm 5$ & $11(0-17)$ \\
Doğal Oluşum & $39.5 \pm 19.5$ & $36(7-79)$ \\
Afet & $0.58 \pm 1.1$ & $0(0-3)$ \\
\hline Toplam & $223 \pm 74$ & $222(98-408)$ \\
\hline
\end{tabular}

SS: Standart Sapma

Oluşturulan anlam kategorilerindeki sözcüklerin sözcüğü sözcüğüne çeviri, yerlileştirme ve yabancılaştırma yöntemlerine göre çevrilme yüzdelerine ilişkin tanımlayıcı istatistikler Tablo 5'de verilmiştir.

Tablo 5. 48 Kitabın 10'ar Sayfasında Çevre ile İlgili Sözcük Sayılarının Anlam Kategorilerine Göre Dă̆̆lımına İlişkin Tanımlayıcı İstatistikler

\begin{tabular}{|c|c|c|c|c|c|c|}
\hline \multirow[b]{2}{*}{$\begin{array}{c}\text { Anlam } \\
\text { Kategorileri }\end{array}$} & \multicolumn{2}{|c|}{$\begin{array}{c}\text { Sözcüğü Sözcüğüne } \\
\text { Çeviri }(\%)\end{array}$} & \multicolumn{2}{|c|}{ Yerlileştirme (\%) } & \multicolumn{2}{|c|}{ Yabancılaştırma (\%) } \\
\hline & Ort \pm SS & $\begin{array}{c}\text { Ortanca } \\
\text { (Min- } \\
\text { Maks) }\end{array}$ & Ort \pm SS & $\begin{array}{c}\text { Ortanca } \\
\text { (Min- } \\
\text { Maks) }\end{array}$ & Ort \pm SS & $\begin{array}{c}\text { Ortanca } \\
\text { (Min- } \\
\text { Maks) }\end{array}$ \\
\hline Fauna & $42.2 \pm 21.2$ & $\begin{array}{c}43.9 \\
(0-76.2)\end{array}$ & $57 \pm 21.6$ & $\begin{array}{c}56 \\
(19.1-100)\end{array}$ & $0.78 \pm 1.5$ & $\begin{array}{c}0 \\
(0-4.8)\end{array}$ \\
\hline Flora & $43.6 \pm 24.3$ & $\begin{array}{c}50.9 \\
(0-87.5)\end{array}$ & $54.2 \pm 23.6$ & $\begin{array}{c}47.2 \\
(12.5-100)\end{array}$ & $2.3 \pm 4.5$ & $\begin{array}{c}0 \\
(0-20)\end{array}$ \\
\hline $\begin{array}{l}\text { Yeryüzü } \\
\text { Şekilleri }\end{array}$ & $31.9 \pm 21.6$ & $\begin{array}{c}34.3 \\
(0-70)\end{array}$ & $66.4 \pm 22.9$ & $\begin{array}{c}65.7 \\
(29.2-100)\end{array}$ & $1.6 \pm 3$ & $\begin{array}{c}0 \\
(0-9.7)\end{array}$ \\
\hline
\end{tabular}




\begin{tabular}{|c|c|c|c|c|c|c|}
\hline \multirow[b]{2}{*}{ Yer Adları } & \multicolumn{2}{|c|}{$\begin{array}{l}\text { Sözcüğ̈̈ Sözcüğ̈une } \\
\text { Çeviri }(\%)\end{array}$} & \multicolumn{2}{|c|}{ Yerlileştirme (\%) } & \multicolumn{2}{|c|}{ Yabancılaştırma (\%) } \\
\hline & $20.5 \pm 20.2$ & $\begin{array}{c}17.4 \\
(0-85.7)\end{array}$ & $45.6 \pm 32.4$ & $\begin{array}{c}38.8 \\
(0-100)\end{array}$ & $33.9 \pm 32.5$ & $\begin{array}{c}28.2 \\
(0-100)\end{array}$ \\
\hline $\begin{array}{l}\text { Hayvan } \\
\text { Yaşam } \\
\text { Alanları }\end{array}$ & $49.9 \pm 31.5$ & $\begin{array}{c}50 \\
(0-100)\end{array}$ & $46.7 \pm 31.3$ & $\begin{array}{c}48.2 \\
(0-100)\end{array}$ & $3.3 \pm 18.3$ & $\begin{array}{c}0 \\
(0-100)\end{array}$ \\
\hline $\begin{array}{c}\text { Hava/İklim } \\
\text { Koşulları }\end{array}$ & $41.7 \pm 25.5$ & $\begin{array}{c}45.5 \\
(0-100)\end{array}$ & $58.1 \pm 28.5$ & $\begin{array}{c}53.9 \\
(0-100)\end{array}$ & $0.2 \pm 1.3$ & $\begin{array}{c}0 \\
(0-8.3)\end{array}$ \\
\hline $\begin{array}{l}\text { Doğal } \\
\text { Oluşum }\end{array}$ & $41.9 \pm 23.6$ & $\begin{array}{c}44 \\
(3.3-77.3)\end{array}$ & $57.6 \pm 23.9$ & $\begin{array}{c}54.1 \\
(22.7-96.7)\end{array}$ & $0.5 \pm 1.5$ & $\begin{array}{c}0 \\
(0-5.1)\end{array}$ \\
\hline Afet & $19.4 \pm 38.8$ & $\begin{array}{c}0 \\
(0-100)\end{array}$ & $80.6 \pm 38.8$ & $\begin{array}{c}100 \\
(0-100)\end{array}$ & $0.5 \pm 1.5$ & $\begin{array}{c}0 \\
(0-0)\end{array}$ \\
\hline
\end{tabular}

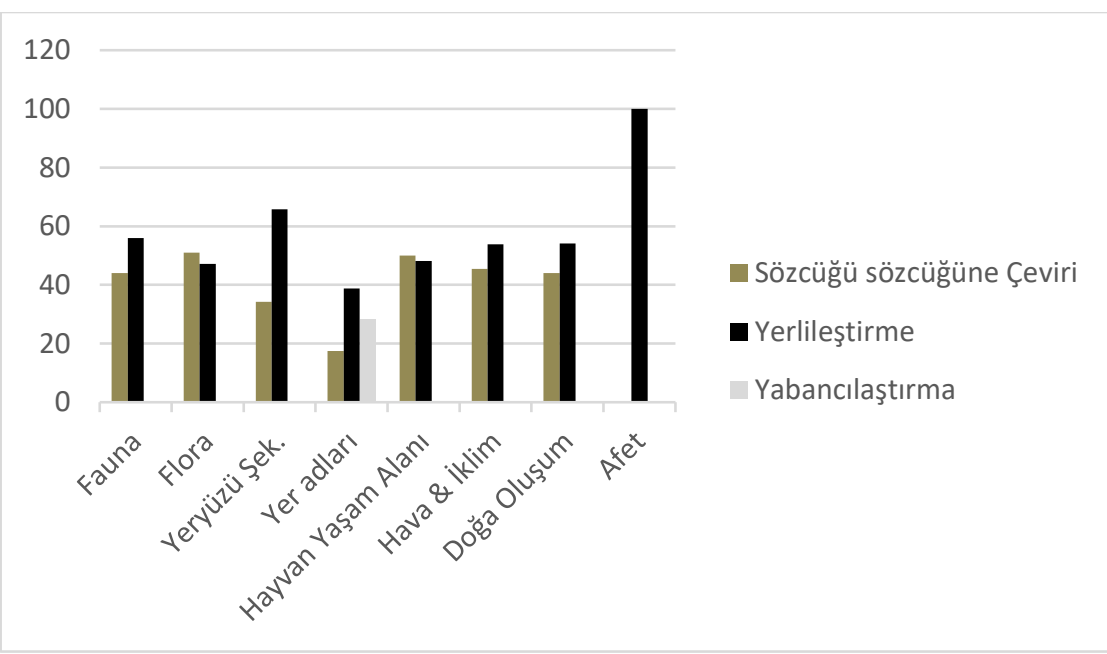

Grafik 2. Çevre Alt Kategorilerinin Çevirilerinde Yöntem Ortancalarının Dağılımı

Grafik 2'den de görüleceği gibi, Fauna, Flora, Hayvan/Yaşam Alanları, Hava/İklim Koşulları ve Doğal oluşum kategorilerinde çok benzer olarak sözcüklerin yaklaşık yarısının (\%47,2-\%56) yerlileştirme yöntemi ile geri kalanların ise sözcüğü sözcüğüne çeviri yapılarak çevrildiği gözlenmektedir. Afet kategorisine ait sözcüklerin hemen hemen tamamı Yerlileştirme yapılarak çevrilirken, Yeryüzü şekilleri kategorisindekilerin de \%65,7'si yerlileştirme, geri kalanı sözcüğü sözcüğüne çeviri yöntemi ile çevrilmektedir. En farklı örüntüye Yer Adları kategorisinde rastlanmakta olup \%38.8'i 
Yerlileştirme, \%17,4'ü Sözcüğü Sözcüğüne Çeviri ve \%28,2'si Yabancılaştırma yöntemi ile çevrilmiştir.

\section{3 Çeviri Yöntemlerinin Dönemsel Dă̆ıllımı}

Artsüremli ve erek dil odaklı bir bakış açısıyla, yaşanan politik süreçlerin politik izdüşümlerini çeviri ürünlerinde takip edebilmek ve oluşan çeviri ürünlerdeki özellikleri ülkenin sosyo-politik dokusuyla bağdaştırabilmek için bu çalışma kapsamında üç temel tarihsel dönem (1929-1960, 1961-1980, 19812013) ele alınmıştır. Cumhuriyet tarihi boyunca çeviri davranışları ülkedeki ideolojik yapılanma ve politik gündemle yakından ilişkili olmuştur. Erken Cumhuriyet döneminde harf devrimiyle (1928) ivme kazanan, Tercüme Bürosu'nun kurulması (1940-1967) ile bir kültür repertuarı oluşturma aracı haline gelen çeviri hareketleri, çok partili döneme geçişin, 1960, 1971 ve 1980 askerî darbelerinin, 2002 sonrası AKP hükümeti ile gelen muhafazakâr dinamiklerin yaşandığı süreçte değişen siyasi dengelerin çeviri süreçleri açısından etkili olduğu farklı tarihsel çalışmalarla ele alınmıştır (TahirGürçağlar, 2008; Oktar ve Kansu-Yetkiner, 2012; Arslan, 2016). Bu dönemlerdeki sosyo-politik ve kültürel atmosfere ilişkin saptamalarda bulunmak çeviri yöntemlerinin tarihsel seyrini yorumlamak açısından yerinde olacaktır.

$\mathrm{Bu}$ amaçla, 48 kitabın 10'ar sayfasında sözcüğü sözcügüne çevrilen, yerlileştirilerek ve yabancılaştırılarak çevrilen doğa ile ilgili toplam sözcük sayılarının dönemlere göre dağılımı ele alınmış ve dönemler arası yöntem kullanım farkının istatistiksel olarak anlamlı olup olmadığı hesaplanmıştır (Tamamlayıcı istatistikler için bkz. Tablo 6).

1929-1960 yılları arasında çevrilmiş 8, 1961-1980 yılları arasında çevrilmiş 19 ve 1981-2013 yılları arasında çevrilmiş 21 kitabın 10'ar sayfası incelendiğinde sözcüğü sözcüğüne çevrilen, Yerlileştirilen ve Yabancılaştırılan kitap başına düşen doğa ile ilgili sözcük ortalamalarının oldukça benzer olduğu görülmektedir (bkz. Tablo 6).

Sözcüğü sözcüğüne çevrilen sözcük ortalaması 1929-1960 yılları arasında ortalama $94,5 \pm 61,1,1961-1980$ y1llar1 arasinda $90,1 \pm 53,6$ ve 1981-2013

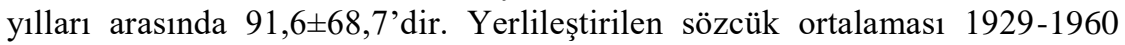
y1lları arasinda ortalama $102,1 \pm 50,4,1961-1980$ yılları arasinda $119,6 \pm 55,5$ ve 1981-2013 yılları arasında $137,3 \pm 53,9^{\prime}$ dur. Yabancılaştırılan sözcük

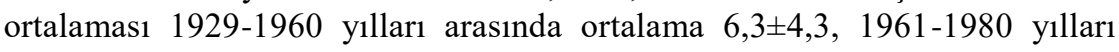

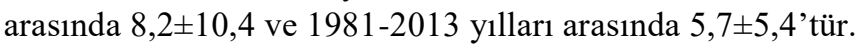


Tablo 6. 48 Kitabın 10’ar Sayfasında sözcüğ̈̈ sözcüğ̈̈ne, Yerlileştirilerekve Yabancılaştırılarak Çevrilen Doğa ile Ilgili Toplam Sözcük Sayılarının Dönemlere Göre Dă̆llımlarına İlişkin Tanımlayıcı Istatistikler

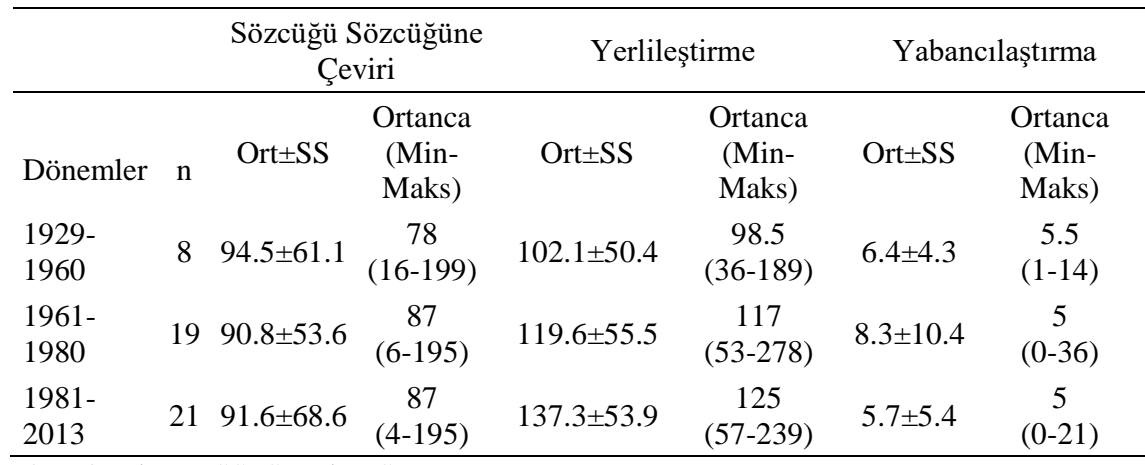

Ort: Ortalama, SS: Standart Sapma

Çeviri yöntemleri arasındaki farkın dönemsel olarak anlamlı olup olmadığı Kruskal Wallis Varyans Analizi ile hesaplanmıştır (bkz. Tablo 7).

Tablo 7. 48 Kitabın 10'ar Sayfasında Doğa ile Ilgili Sözcüklerin Dönemlere Göre Sözcüğü Sözcüğ̈̈ne Çeviri, Yerlileştirme ve Yabancılaştırma Yapılarak Çevrilme Yüzdeleri

\begin{tabular}{|c|c|c|c|c|c|c|c|}
\hline \multirow[b]{2}{*}{ Dönemler } & \multirow[b]{2}{*}{$\mathrm{n}$} & \multicolumn{2}{|c|}{$\begin{array}{c}\text { Sözcüğü Sözcügüne } \\
\text { Çeviri }(\%)\end{array}$} & \multicolumn{2}{|c|}{ Yerlileştirme (\%) } & \multicolumn{2}{|c|}{ Yabancılaştırma (\%) } \\
\hline & & Ort \pm SS & $\begin{array}{c}\text { Ortanca } \\
\text { (Min-Maks) }\end{array}$ & Ort $\pm S S$ & $\begin{array}{c}\text { Ortanca } \\
\text { (Min-Maks) }\end{array}$ & Ort \pm SS & $\begin{array}{c}\text { Ortanca } \\
\text { (Min-Maks) }\end{array}$ \\
\hline $1929-1960$ & 8 & $45.9 \pm 19.6$ & $\begin{array}{c}47.6 \\
(7.6-73.2)\end{array}$ & $50.8 \pm 19.8$ & $\begin{array}{c}46.4 \\
(25-89.6)\end{array}$ & $3.3 \pm 2.1$ & $\begin{array}{c}3 \\
(0.6-6.4)\end{array}$ \\
\hline $1961-1980$ & 19 & $39.8 \pm 18.9$ & $\begin{array}{c}38.5 \\
(6.1-68.7)\end{array}$ & $55.8 \pm 20.2$ & $\begin{array}{c}57.6 \\
(29.2-92.9)\end{array}$ & $4.4 \pm 6.1$ & $\begin{array}{c}2.1 \\
(0-22.1)\end{array}$ \\
\hline $1981-2013$ & 21 & $35.8 \pm 22.9$ & $\begin{array}{c}40 \\
(2.9-67)\end{array}$ & $61.7 \pm 24.3$ & $\begin{array}{c}59.5 \\
(29.9-97.1)\end{array}$ & $2.4 \pm 2.1$ & $\begin{array}{c}2.6 \\
(0-7.5)\end{array}$ \\
\hline $\mathrm{p}^{*}$ & & & $>0.05$ & & $>0.05$ & & $>0.05$ \\
\hline
\end{tabular}

*Kruskal Wallis Varyans Analizi

1929-1960 y1lları arasında yazılan kitaplarda sözcüklerin \%47,6'sının sözcüğü sözcüğüne çevri yoluyla çevrildiği, bu oranın 1961-1980 yılları arasındaki kitaplarda \%38,5 ve 1981-2013 aras1 kitaplarda \%40 olduğu görülmüştür. 1929-1960, 1961-1980 ve 1981-2013 yılları arasında yazılan kitaplarda sözcüklerin yerlileştirme yoluyla çevrilme oranları sırasıyla \%46,4, \%57,6 ve $\% 59,5$ iken yabancılaştırma yoluyla çevrilme oranları $\% 3, \% 2,1$ ve \%2,6'dır. 1960 sonrası yapılan çevirilerde Yerlileştirme yoluyla çeviri 
oranları artmış, Sözcügü Sözcüğüne Çeviri ve Yabancılaştırma yoluyla çeviri oranları düşmüş olsa da fark her üç yöntem için de önemli düzeyde bulunmamıştır $(\mathrm{p}>0,05)$.

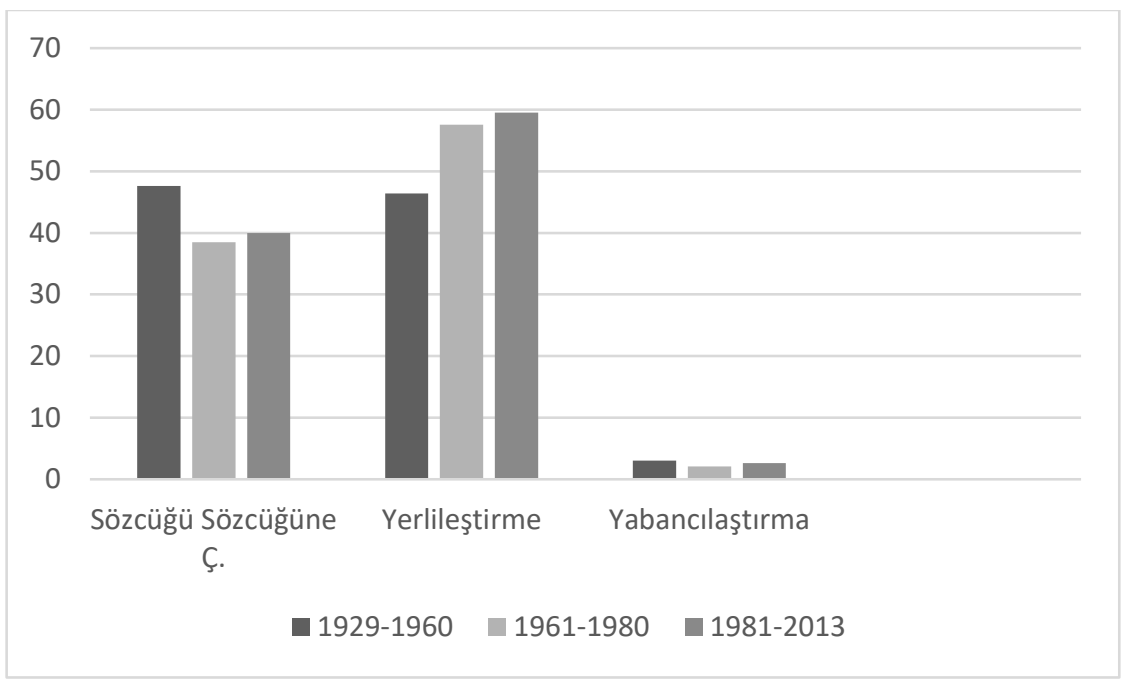

Grafik 3. Çeviri Yöntemlerinin Dönemsel Dağılımı

\section{Sonuç ve Tartışma}

$\mathrm{Bu}$ çalışma geniş bir bütünce kapsamında, niceliksel verilerle, ölçülebilir ve takip edilebilir parametrelerle çeviribilim çalı̧̧alarının yapılabileceğini ortaya koymaktadır. Ayrıca, çeviribilim açısından yeni bir çalışma sahasına işaret ederek ekoçeviri, ekoeleştiri ve çeviribilim alanlarını birleştirmesi ve Türkiye'de çevre duyarlılığının kültürlerarası aktarımını irdelemesi açısından bir ilktir. Çeviribilim, çevre ve ekoloji etkileşimine dair gelecekteki çalışmalara ışı tutacak, çevre konusunda "sorumlu çevirmen davranışı" sergilenmesini sağlayacak bir farkındalık yaratmaktadır. Diğer taraftan, kültürel tarihin merkezinde yer alan çeviri toplumsal, ekonomik, ideolojik ve kültürel paradigmalardaki değişiklikleri etkileyen ve bunlardan etkilenen bir olgudur. $\mathrm{Bu}$ nedenle niceliksel bulguların belirlenen dönem içindeki sosyo-ekonomik ve ideolojik dinamiklerle bağdaştırılması, çözümleyici bakış açısı yönünden çeviri davranışlarının nedenlerini saptamak için gereklidir. Bu bakımdan, hem niceliksel verilerin hem de toplumsal olayların artsüremli olarak değerlendirmesi açısından çalışmamız önemli bir örnek teşkil etmektedir. Bu noktadan hareketle, çeviri eserlerin ülkemizdeki kültür yaşamına politik, 
ekonomik ve ideolojik açıdan etkilerini göz önüne alarak bulgularımıza tarihsel bağlamda bir açıklama getirmek yerinde olacaktır.

Artsüremli ve erek dil odaklı bir bakış açısına sahip olan çalışmamızda yaşanan tarihsel süreçlerin izdüşümlerini çeviri metinler ve çeviri kararları üzerinde takip edebilmek ve oluşan çeviri ürünlerdeki özellikleri ülkenin sosyo-politik dokusuyla bağdaştırabilmek için üç temel tarihsel dönem (19291960, 1961-1980, 1981-2013) ele alınmıştır. Bu dönemlerdeki sosyo-politik ve kültürel atmosfere ilişkin saptamalarda bulunmak çeviri yöntemlerinin tarihsel seyrini yorumlamak açısından önem arz etmektedir.

Yöntemlere ilişkin genel dağılıma bakacak olursak, bulgularımıza göre, çeviri yöntemlerinin dönemsel farklılıkları arasında istatistiksel olarak anlamlı bir fark bulunamamıştır. Çeviri yöntemleri arasında yerlileştirmenin egemen olduğu, ardından sırasıyla sözcüğü sözcüğüne çeviri ve yabancılaştırma yönteminin geldiği görülmektedir. Ancak, yöntemlerin kendi başına tarihsel seyrine baktığımızda, çeviri yöntemlerine ilişkin tutumun tarihsel olaylar ile koşutluk gösterdiği görülmektedir.

Harf devriminin ardından modern Türk alfabesine geçiş, hem yeni alfabeyle özgün eserlerin yazılmasını hem de Osmanlıca yazılmış veya Osmanlıcaya çevrilmiş eserlerin dil içi çevirilerle çağdaş Türkçeye kazandırılmasını gerektirmiştir. Erken Cumhuriyet döneminde Mustafa Kemal Atatürk'ün laiklik, Türk milliyetçiliği ve Batı odaklı bir modernizm ile yoğrulan resmî devlet ideolojisi, Avrupa odaklı Batı uygarlığının evrensel değerlerini benimsemiştir. Erken Cumhuriyet dönemi içinde Tercüme Bürosu'nun kurulmasında Türk halkındaki batılılaşma için gereken altyapı eksiklikleri gidermeye yardımcı olacak yeni düşünce biçimlerinin ithalini meşrulaştıran bir söylem benimsenmiştir (Tahir-Gürçağlar, 2008). Bir diğer deyişle, eğitimin ve çağdaşlaşma sürecinin ülke kalkınmasındaki öneminin bilicinde olarak genç cumhuriyet, gereksinim duyulan ideolojik ve kültürel zemini yaratmak için çeviriye başvurmuş, bu süreci denetimli ve cumhuriyet felsefesine uygun sürdürebilmek için zamanın Milli Eğitim Bakanı Hasan Âli Yücel önderliğinde Tercüme Bürosu'nu kurmuştur. Batııı mümkün olduğunca derinden özümsemek için bu dönemdeki çeviri yönteminin, ithal edilecek malzemenin hiçbirini göz ardı etmeyecek şekilde olabildiğince sadık, kolay okunabilir ve anlaşılabilir bir Türkçe ile özgün metnin sanatsal, düşünsel ve estetik özelliklerini koruyarak çeviri yapmak şeklinde belirlendiği görülmektedir (Aksoy, 2001). Bu dönemde görülen sözcügüu sözcüğüne çeviri yani “öteki”yi doğrudan alma ve özümseme çabası Tercüme Bürosu etrafında çevrelenen söylemi doğrular niteliktedir. Nitekim Türkiye tarihi boyunca en yoğun sözcüğü sözcüğüne çeviri ve en az yerlileştirme yöntemi kullanımı bu dönemde gözlemlenmiştir. Yabancılaştırma stratejilerinin her üç dönemde de diğer iki yöntemin çok gerisinde kaldığı görülmektedir. Ancak yine 19291960 dönemine tekabül eden erken Cumhuriyet döneminde en fazla 
yabancılaşma yönteminin kullanılmasında Tercüme Bürosu'nun üstünde durduğu yabancı özel isimlerin hiç değişikliğe uğratılmadan aynen yazılması normunun (Tahir-Gürçağlar, 2008) kullanılmasının da etkisinin büyük olduğu söylenebilir.

1960 sonrası dönemde sağ ve sol cephesinden oluşan politik kutuplaşma, 12 Mart 1971 ihtilalini beraberinde getirmiş, ortaya çıkan durum entelektüel bilgiyi devletin denetiminde ithal etmekten uzaklaştırmış ve farklı politik çevrelere ve gruplara yönelik talepler ortaya çıkmıştır. Şöyle ki, Tercüme Bürosu'nun 1966'da kapanmasının ardından kristalleşen politik tercihlere yanıt vermek üzere özel yayınevleri kendi amaç ve hedeflerine hizmet eden kitaplar çevirtmiş veya yayınlamıştır (Tahir-Gürçağlar, 2008). 12 Mart 1971 darbesini takiben, yurt genelinde sürekli hale gelen ve yaygınlaşan sağ-sol kavgası, partiler arası bitmek bilmeyen anlaşmazlıklar ve toplum içerisinde yeniden oluşan ciddi bir siyasi kutuplaşma, on y1l sonra 12 Eylül 1980'de bir başka askerî darbeye yol açmıştır. 1961-1980 döneminde belirleyici olan Tercüme Bürosu'nun kapatılmasıyla birlikte oluşan politik kristalleşmeye hizmet eden karışık taleptir. Peş peşe gelen ihtilallerle gelişen içe kapanma yoğun yerlileştirme sürecini de beraberinde getirmiş, Cumhuriyet değerlerinin ön gördüğü Batıyı tanıma ve anlama anlayışı sağ ve sol gruplar için yörünge değiştirmiştir. Bu nedenle, üç askerî darbeyi barındıran 1961-1980 döneminde sırasıyla yerlileştirme, sözcüğü sözcüğüne çeviri ve yabancılaştırma yöntemlerinin benimsendiği görülmektedir.

İncelediğimiz son döneme geldiğgimizde, 1982 Anayasası'nın kabulü ile Atatürkçülük devletin ve bütün siyasi partilerin uyması gereken bir ideoloji olarak yer almış, Türkiye'nin yeni eğitim politikası Türk milli değerlerine ve kültürüne uygun olarak Atatürkçülük ile İslam'1 sentezleyen milliyetçi bir anlayış çerçevesine sokulmuştur (Kaplan, 2011). 1981-2013 dönemi içinde Cumhuriyet tarihi kapsamında yerlileştirmenin en fazla oranda kullanımı da ülkedeki sosyo-politik olaylarla ve ülkenin değişen paradigmasıyla doğrudan ilintilidir. Ülkede son ylllarda belirginleşen muhafazakâr İslami söylemin yansımaları özellikle 100 Temel Eser kapsamında Türkçeye çevrilen dünya çocuk klasikleriyle gözlemlenmiştir. Ülkedeki sosyo-politik olaylara paralel olarak çeviride süreç ve ürün açısından bir denetimsizlik, dolayısıyla bir çeşitlilik döneminin yaşandı̆̆ını söyleyebileceğimiz bu süreçte, telif gerektirmeyen eserler farklı yayınevleri tarafından çoğu kez İslami değerlerle bezenmiş bir yerlileştirme hareketi ile tekrar tekrar basılmış veya yeniden yazılmıştır (Kansu-Yetkiner, 2014; Daldeniz, 2010). Bu gelişmelere ve diğer araştırma bulgularına koşut olarak, bizim çalışmamızda da yerlileştirme stratejisine yönelik artan bir eğilim gözlenmiştir. Ele alınan diğer dönemlere kıyasla, en çok yerlileştirme stratejisi son dönemde gerçekleşmiştir. 
Sonuç olarak, çalışmamız ulusal edebiyat dizgesi içinde yer alan çeviri çocuk edebiyatı dizgesinin oluşturulması sürecine artsüremli bir bakış açısıyla yaklaşarak çeviri stratejilerine odaklanmıştır. Sözcüğü sözcüğüne çeviri, yerlileştirme ve yabancılaştırma ekseninde ele alınan bulgular, çevirinin çoklu değişkenleri içinde barındıran sosyo-politik ve kültürel bir eylem olduğunu ortaya koymaktadır (Tahir-Gürçağlar, 2003; Venuti, 1998). Bulgularımız, çocuk yazını içinde giderek daha çok yerlileşmeye yer veren bir çeviri eğilimi olduğunu ortaya koymuştur. Çocuk yazını çevirilerinin kültürlerarası bir edinim eşiği olduğu gerçeği, özellikle yabancı eserlerin seçimi ve çevirisinde, çeviri yöntemlerinin belirlenmesinde dikkate alınması gereken önemli bir konudur. Erken Cumhuriyet dönemi haricinde, çocuk edebiyatı çevirilerinde egemen olan yerlileştirme yönteminin kullanılması, Türkiye'deki çeviri çocuk edebiyatı içinde genel eğilimlere (Shavit, 1986; Klinberg, 1986; Puurtinen, 1993) uygun bir seyrin gözlemlendiğini ortaya koymaktadır. 10 İngilizce özgün kitap ve bunların 48 yeniden çevirisinden oluşan geniş bir veri tabanı içinde yapılan bu kapsamlı çalışmada, giderek yerlileştirme yöntemine dönüşen bir çeviri anlayışı çocuk okurun "farklı", "öteki” olan çevreye ilişkin kültürel unsurlara ulaşamamasına, farklı kültürlerin çevre/doğa ve ekosisteme ait tutum ve davranışları öğrenememesine yol açmaktadır. Yerlileştirme, hem bilgi aktarım yükünü hafifletmekte hem de çevre ve doğaya ilişkin kaynak kültürün söyleminde bir sapmaya neden olarak kültürlerarası etkileşimi engelleyebilmektedir. Yabanc1 ayrıntıların yok edilmesi, erek metinde bir akıcılık yaratma hedefiyle sıra dışı ögelerin sıradanlaştırılması, bunların bilindik ögelerle anlatılması şeklinde karşımıza çıkan yerlileştirme stratejileri, çocuk okuru yabancı ögeleri anlamaktan ve öğrenmekten mahrum etmekte, kültürlerarası aktarımı anlatının aktarımı düzeyinde bırakarak bilgi yükünün ve çevreye yönelik ahlaki tutum ve davranışların taşınmasını engellemektedir.

Hiç şüphe yok ki, çevre odaklı sözcüklerle yapılan bu içerik çözümlemesi, sınırlı bir veri tabanı ve çocuk edebiyatı dizgesi kapsamında gerçekleşmiş, niceliksel veri odaklı bir çalışmadır. Niceliksel verilerin sosyo-politk ve kültürel olaylarla bağdaştırılması daha geniş kapsamlı ve derinlemesine çözümlemeler gerektirmektedir. $\mathrm{Bu}$ nedenle, araştırma sonuçlarını tüm edebiyat dizgesini göz önüne alarak genellemek okuru yanlış yönlendirebilir. Farklı kültür bileşenleri düşünülerek daha geniş bütünce çerçevesinde farklı dillerdeki çeviriler de eklenerek yeni bir araştırma deseni oluşturulabilir. Ayrıca, belirli kültür ögeleri veya tabu sayılan konular çerçevesinde yetişkin edebiyatı odaklı bir bütünce ile kültürlerarası aktarımları sosyo-politik süreçle bağlantılandırarak incelemek de bu çalışmanın açtığı kapılardan birisi olabilir. 


\section{Kaynaklar}

Aixela, J. F. (1996). Culture-specific items in translation. R. Alvarez ve C. Africa Vidal (haz.), Translation, power, subversion (s. 52-78). Frankfurt: Multilingual Matters.

Aksoy, B. (2001). Translation as rewriting: the concept and its implications on the emergence of a national literature. Translation Journal, 5(3). Erişim adresi http://accurapid.com/journal/16prof.htm.

Arslan, D. U. (2016). Translation, obscenity and censorship in Turkey: Avni Insel as a translator and patron of popular erotic literature (Yüksek lisans tezi). Dokuz Eylül Üniversitesi, İzmir.

Bassnett, S. \& Lefevere, A. (1990). Translation, history and culture. London: Printer Publishers.

Baker, M. (1992). In other words. London: Routledge.

Baratz, L. \& Hazeria, H. A. (2012). Children's literature as an important tool for education of sustainability and the environment. International Electronic Journal of Environmental Education, 2 (1), 31-36.

Birkan Baydan, E, (2010). Ideology Unveiled Islamist Retranslations of the Western Classics, Saarbrücken: Lambert Academic Publishing.

Cronin, M. (2015). The moveable feast: translation, ecology and food, The Translator, 21(3), 244-256.

Cronin, M. (2017). Ecotranslation:translation and ecology in the age of Anthropocene. Abingdon and NewYork: Routledge.

Çıkla, S. (2005). Tanzimattan günümüze çocuk edebiyatı ve bazı öneriler. Hece Dergisi Çocuk Edebiyatı Özel Sayısı, 104/105, 89-107.

Daldeniz, E. (2010). Islamic publishing houses in transformation: the role of translation. Translation Studies, 3 (2), 216-230.

Florin, S. (1993). Realia in translation. P. Zlateva (haz.), Translation as social action. Russian and Bulgarian perspectives (s. 122-128). London: Routledge.

Frank, H. T. (2007). Cultural encounters in translated children's literature: images of Australia in French translation. Manchester: St. Jerome Publishing.

Goodenough, W. H. (1964). Cultural anthropology and linguistics. D. Hymes (haz.), Language in culture and society. A reader in linguistics and anthropology (s. 3639). New York: Harper \& Row.

Güran Yiğitbaş1, K. (2014). Türkiye'de çocuk dergiciliği: TRT Çocuk Dergisi örneği. Ĭgdır Üniversitesi Sosyal Bilimler Dergisi, 5, 37-56.

Hostova, I. (2016). Of ecosystems and Translations: some ways of translating nontraditional texts. World Literature Studies, 8, 74-85.

Hunt, P. (1994). An introduction to children's literature. Oxford: Oxford University Press.

Kansu-Yetkiner, N. (2014). Words apart, worlds apart: peritexts from Islamized translations of world classics in children's literature. Children's Literature in Education An International Quarterly, 45 (4), 340-353.

Kaplan, İ. (2011). Türkiye'de milli eğitim ideolojisi. İstanbul: İletişim.

Klingberg, G. (1986). Children's fiction in the hands of the translator. Malmo: Liber/Gleerup. 
Lefevere, A. (1992). Translation, rewriting, and the manipulation of literary fame. London/New York: Routledge.

Newmark, P. (1988). Textbook of translation. Oxford: Pergamon.

Neydim, N. (2000). 80 sonrası paradigma değişimi açısından çeviri çocuk edebiyatı (Doktora tezi). İstanbul Üniversitesi, İstanbul.

Neydim, N. (2003). Türkiye'de çeviri çocuk edebiyatının gelişimi ve bu gelişimde Fransız dili ve aydınlanmasının etkisi. Çeviribilim ve Uygulamaları Dergisi, 13, 7993.

Neydim, N. (2006). Masumiyetini tamamen kaybeden seçki: 100 Temel Eser. Radikal. Erişim adresi: http://www.radikal.com.tr/yorum/masumiyetini-tamamen-kaybedensecki-100-temel-eser-790253/

Oktar, L. \& Kansu-Yetkiner, N. (2012). Different times, different themes in Lady Chatterley's Lover: a diachronic critical discourse analysis of translator's prefaces. Neohelicon, Acta Comparationis Litterarum Universarum, 39 (2), 337-364.

Puurtinen, T. (1993). Perspectives on the Translation of Children's Literature. içinde S. Tirkkonen ve J. Lafflings. Recent Trends in Enprical Translation Research.(s. 2538). Joensuu: University of Joensuu.

Puurtinen, T. (1998). Syntax, readability and ideology in children's literature. Meta, 43 (4), 1-9.

Roth, C. E. (1992). Environmental Literacy: Its Roots, Evolution and Directions in the 1990s. ERIC. Erişim adresi: https://eric.ed.gov/?id=ED348235

Shavit, Z. (1986). Poetics of children's literature. Athens/London: University of Georgia Press.

Tahir-Gürçağlar, Ş. (2003). The translation Bureau revisited:translation as symbol. İçinde M. Calzada-Perez (Ed.), Apropos of ideology ( s. 113-129). Manchester: St. Jerome.

Tahir-Gürçağlar, Ş. (2008). The politics and poetics of translation in Turkey, 1923-1960. Amsterdam/New York: Rodopi.

Tuncer, N. (1995). Chidren's literature in Turkey. Türk Kütüphaneciliği Dergisi, 9 (3), 268-269.

Valero Garcés, C. (2011). Ecociticism and translation. Odisea, 12, 257-272.

Venuti, L. (1995). The translator's invisibility: A history of translation. London/New York: Routledge.

Venuti, 1. (1998). The scandals of translation: Toward ethnics of difference. London: Routledge.

\section{Çalışmaya Konu Olan Kaynaklar}

Ballantyne,R.M.(1858). The coral island. Erişim adresi http://pinkmonkey.com/ dl/library1/digi453.pdf.

Ballantyne, R. M. (1943). Mercan adası (N. Ataç, Çev.). İstanbul: Kanaat.

Ballantyne, R. M. (1967). Mercan adası (M. D. Özbay, Çev.). İstanbul: Zühal.

Ballantyne, R. M. (1980). Mercan adası (G. Suveren, Çev.). Altın.

Ballantyne, R. M. (1999). Mercan adası (M. Cagnino, Çev.). İstanbul: Boyut.

Ballantyne, R. M. (2007). Mercan adası (D. Işık, Tashih). İstanbul: Birleşik Tomurcuk. 
Golding, W. (1954). The lord of the flies. Erişim adresi http://www.pdfdrive.net/homepage-title-page-lord-of-the-flies-global-village-e220394.html.

Golding, W. (1969). İște bizim dünya (Ö. Süsoy, Çev.). Habora.

Golding, W. (1979). Sineklerin tanrısı (M. Urgan, Çev.). Milliyet.

Golding, W. (1994). Çocuk adası (Ö. Savuran, Çev.). İstanbul: Ya-Pa.

Grahame, K. (1908). The wind in the willows. Erişim tarihi http://pinkmonkey.com/ d1/library1/wind.pdf.

Grahame, K. (1972). Dört arkadaş (K. Akçalı, Çev.). İstanbul: Armağan.

Grahame, K. (1986). Sögüt ăgaçlarında rüzgar (L. Onat, Çev.). Ankara: İlk Kaynak.

Grahame, K. (2011). Söğ̈̈tlerde rüzgar (B. Adalı, Çev.). İstanbul: Yapı Kredi.

Hodgson Burnett, F. (1911). The secret garden. Erişim adresi http://www.feedbooks.com/ book/6578/the-secret-garden.

Hodgson Burnett, F. (1944). Esrarlı bahçe (N. Milâr, Çev.). İstanbul: Ahmet Halit Kitabevi.

Hodgson Burnett, F. (1969). Esrarlı bahçe (N. Yalaza Taluy, Çev.). İstanbul: Varlık.

Hodgson Burnett, F. (1978). Gizli bahçe (G. Suveren, Çev.). Altın.

Hodgson Burnett, F. (1991). Gizli bahçe (İ. Eti, Çev.). İstanbul: Engin.

Hodgson Burnett, F. (2011). Gizli bahçe (D. Denizci, Çev.). İstanbul: Can.

Kipling, R. (1894). The jungle book. Erişim adresi freekidsbooks.org/download/219.

Kipling, R. (1936). Cengel kitabı (N. Artam, Çev.). Ankara: Ulus Gazetesi.

Kipling, R. (1954). Kurt çocuk (N. Yalaza Taluy, Çev.). İstanbul: Doğan Kardeş.

Kipling, R. (1965). Yavru kurt (G. Tunara, Çev.). İstanbul: Varlık.

Kipling, R. (1973). Orman masalı (K. Akçalı, Çev.). İstanbul: Armağan.

Kipling, R. (1995). Orman çocuğu (A. Kanar, Çev.). İstanbul: Morpa.

Kipling, R. (2009). Cengel kitabı (K. Mengütürk, Çev.). İstanbul: Yap1 Kredi.

Kipling, R. (1897). Captains courageous. Erişim adresi http://www.feedbooks.com/ book/3584/captains-courageous.

Kipling, R. (1964). Korkusuz kaptanlar (G. Sayar, Çev.). Ak.

Kipling, R. (1976). Korkusuz kaptanlar (G. Suveren, Çev.). Altın.

Kipling, R. (1997). Korkusuz kaptanlar. Ankara: Ünsal.

Kipling, R. (2009). Korkusuz kaptanlar. İstanbul: Sentez.

London, J. (1994) [1903]. The call of the wild. London: Penguin Popular Classsics.

London, J. (1935). Vahşetin çağırışı. İstanbul: Muallim Ahmet Halit Kütüphanesi.

London, J. (1968). Vahşetin çă̆rısı (S. Çağan, Çev.). İstanbul: Kök.

London, J. (1978). Vahşetin çağrısı (B. Taşan, Çev.). İstanbul: Ya-Ba.

London, J. (1984). Vahşetin çağrısı (N. Öztan, Çev.). İstanbul: Serhat.

London, J. (1996). Vahşetin çă̆rısı (M. Ergin, Çev.). İstanbul: Engin.

London, J. (2009). Vahşetin çağrısı (L. Cinemre, Çev.). İstanbul: İş Bankası.

Sewell, A. (1877). Black Beauty. Erişim adresi http://pinkmonkey.com/ d1/library1/digi105.pdf.

Sewell, A. (1965). Siyah İnci (A. Uğur ve E. Uğur, Çev.). İstanbul: İyiGün.

Sewell, A. (1973). Siyah Inci (G. Suveren, Çev.). Altın Çocuk.

Sewell, A. (1997). Siyah İnci (G. Çil, Çev.). İstanbul: Nurdan.

Sewell, A. (2005). Siyah İnci (L. Öksüz, Çev.). İstanbul: Zambak.

Steinbeck, J. (1976) [1933]. The Red Pony. London: Penguin Books. 
Steinbeck, J. (1953). Al Midilli (T. Taga, Çev.). İstanbul: Varlık. Steinbeck, J. (1964). Al Midilli (Ö. Süsoy, Çev.). Altın.

Steinbeck, J. (1976). Al Midilli (S. Anlı, Çev.). İstanbul: Armağan. Steinbeck, J. (1983). Al Midilli (B. Çorakçı, Çev.). İstanbul: Bilgi. Steinbeck, J. (1995). Al Midilli (M. Harmanc1, Çev.). İstanbul: Görsel. Steinbeck, J. (2003). Al Midilli (Ş. Sabırlı, Çev.). İstanbul: Remzi. Stevenson, R. L. (1883). Treasure island. Erişim adresi http://www.planetpublish.com/ wp-content/uploads/2011/11/Treasure_Island_NT.pdf.

Stevenson, R. L. (1939). Define adası (M. Nayir, Hulâsa eden). İstanbul: Kanaat. Stevenson, R. L. (1956). Define adası (N. Arıkan, Çev.). İstanbul: Rafet Zaimler. Stevenson, R. L. (1961). Define adası (E. Uğur, Çev.). İstanbul: İyiGün. Stevenson, R. L. (1970). Define adası (Ö. Süsoy, Çev.). İstanbul: Armağan. Stevenson, R. L. (1983). Define adası (A. Göktürk, Çev.). İstanbul: Can. Stevenson, R. L. (2008). Define adası (N. Elhüseyni, Çev.). İstanbul: İş Bankası. 